\begin{tabular}{ccc} 
FOLI A & ENTOMOLOGICA & HUNGARICA \\
& ROVARTANI KÖZLEMÉNYEK & \\
Volume 80 & 2019 & pp.303-325 \\
\hline
\end{tabular}

\title{
Distribution, life history and conservation assessment of the critically endangered butterfly Pseudolucia parana (Lepidoptera: Lycaenidae)
}

\author{
Dubi Benyamini ${ }^{1 *}$, Nicolás Oliveira Mega ${ }^{2}$, Helena Piccoli Romanowski ${ }^{2}$, Alfred Mose R ${ }^{3}$, \\ Roger VILA ${ }^{4} \&$ Zsolt BÁLINT ${ }^{5}$ \\ ${ }^{1}$ 4D MicroRobotics Ltd., 91 Levona Str., Beit Arye, 7194700 Israel. \\ E-mail:dubi_ben@netvision.net.il \\ ${ }^{2}$ Laboratório de Ecologia de Insetos, Depto. Zoologia, PPG Biologia Animal, Instituto de \\ Biociências. UFRGS - Universidade Federal do Rio Grande do Sul, Porto Alegre, 43435, Brasil. \\ E-mails:hpromano@ufrgs.br,nicolas.mega@gmail.com \\ ${ }^{3}$ Av. Wilhelm Rotermund, 1045-SãoLeopoldo,RS, Brasil.E-mail:a.moser@ensinger.com.br \\ ${ }^{4}$ Institut de Biologia Evolutiva (CSIC-Universitat Pompeu Fabra), \\ Passeig Maritim de la Barceloneta 37, 08003 Barcelona, Spain. E-mail: roger.vila@scic.es \\ ${ }^{5}$ Hungarian Natural History Museum, Department of Zoology, \\ H-1088 Budapest, Baross utca 13, Hungary.E-mail: balint.zsolt@nhmus.hu
}

\begin{abstract}
Pseudolucia parana Bálint, 1993 was described from Castro, Paraná, Brazil, where it was first collected over 120 years ago. It was observed/collected quite sporadically in the second half of the 20th century in a few isolated habitats in the State of Paraná. Excluding a single record since the early 2000s, the species was not observed in all its known sites in Parana due to urbanization of its habitats or change of land use. Consequently the species in Paraná state is highly endangered, possibly extinct. Efforts to find the species in the state Santa Catarina failed. A new hope to the survival of the species appeared in the southernmost state Rio Grande do Sul, where some relict populations are documented. The results of rescue expeditions to several granitic hills in the region are presented and the current distribution $P$. parana is assessed. First descriptions of its early stages, ecology, ethology and recommendations for conservation are given. The data provided indicate that the global status of $P$. parana should be Critically Endangered. Some molecular traits of $P$. parana are analysed resulting in a preliminary assessment for the age of the populations. With 24 figures.
\end{abstract}

Key words - Brazil, campos sulinos, early stages, Paraná, relict, Rio Grande do Sul, south Brazilian grasslands

\footnotetext{
* Corresponding author.
} 


\section{INTRODUCTION}

Brazil is known for its high degree of endemism. In all its regions attractive and rare taxa of butterflies occur, ideal candidates for flagship species for nature protection activities. A good example is the spectacular nymphalid Morpho aega (Hübner, 1822), an endemic species of the Atlantic Forest region. Even the relatively less known family Lycaenidae, represented by two tribes in the Atlantic Forest, offers several species for conservation interests, for example the gorgeous endemic Arcas ducalis (Westwood, 1852), the Ducal Arcas (Brown 1993a). This species belongs to the tribe Eumaeini, which contributes $95 \%$ of Neotropical lycaenid diversity both in species and genera richness (BROWN 1993b, RoBBINs 2004). The number of species of the other tribe, Polyommatini, is extremely low and contains species that rarely attract the interest of non-specialists. In spite of being small and cryptic in pattern and colouration, the study of some key species may help understanding and protect unique threatened ecosystems in the Atlantic Forest.

However, in spite of the fact that the Neotropical region is almost always remembered due to its forested environments, it contains extremely rich nonforested ecosystems that cover almost a third of its area. For example, grasslands are dominant at the southern tip of Brazil, yet areas with well-preserved pristine native fields and vegetation are scarce and diminishing over the years. These remnants are distributed in mosaics in the Atlantic Forest (from Paraná to the Brazilian Southern Plateau of Rio Grande do Sul) and in the Pampa biome (Rio Grande do Sul) and may be called "Campos Sulinos" (ANDRADE et al. 2019). Grassland areas are among the most species-rich ecosystems (Wilson et al. 2012), but are still only very poorly studied and may harbour many unknown and, perhaps, already threatened species. One of these species is Pseudolucia parana Bálint, 1993, the sole representative of the large cosmopolitan subtribe Polyommatina in Brazil (Vil et al. 2011).

In 1902, on the basis of an unstated number of specimens, a small brown to light grey shiny (in fresh specimens) polyommatine butterfly was described from "Castro, Parana" and named Lycaena griqua Schaus, 1902. Since the description, practically no new information on the species appeared in the literature, although it was occasionally collected, and specimens were kept in the collection of Federal University of Paraná (Curitiba, O. Mielke, pers. comm.). In 1992 Zsolt Bálint, while working in the butterfly collection of the British Museum (Natural History) in London (now Natural History Museum, UK), checked a series of 14 male and 2 female specimens of a brown Brazilian lycaenid, identified as L. griqua. The name turned to be a homonym of L. griqua Trimen, 1887. The species looked similar to the widespread austral South American Pseudolucia chilensis (Blanchard, 1852). Specimens were dissected, and it was verified that L. griqua sensu Schaus (1902) indeed belongs to the genus Pseudolucia Nabokov, 1945 and, therefore, the new name Pseudolucia parana was proposed 
(BÁLINT 1993). Subsequently it was found that $P$. parana forms a clade with two other species within the genus Pseudolucia (BÁlint et al. 2000, BÁLINT \& BENYAMINI 2001) and diverged early from the sister P. chilensis (GUERRA SERRUDO et al. 2018; see also later in this paper).

On 31st of December 2007 the type locality ("Castro, Paraná"; GPS $24^{\circ} 47^{\prime} 28^{\prime \prime} S, 50^{\circ} 00^{\prime} 26^{\prime \prime} \mathrm{W}$; elevation $997 \mathrm{~m}$ ) was visited by one of the authors (DB). The site is located in a plateau of grasslands with scattered trees of the Paraná pine (Araucaria angustifolia) called "Campos Gerais". It was inhabited by fifty immigrant Dutch families who turned Castro into a large modern agricultural farm called "Castrolanda". This agro-industrial cooperative produces corn and soybean. Knowing that $P$. chilensis uses Dodders (Cuscuta spp., Cuscutaceae) as host plants (BENYAMINI 1995), an unsuccessful search for these parasitic plants was performed on the "islands" of natural vegetation within the boundaries of Castro. The natural reserve "Canyon Guartela" was also patrolled some $42 \mathrm{~km}$ $\mathrm{NW}$ of Castro with the same results; during three days in Castro no Cuscuta and no $P$. parana were found.

Looking for additional possible habitats for P. parana, DB corresponded with Olaf Mielke, who informed him that there were some specimens of $P$. parana in the collection at Universidade Federal do Paraná, Curitiba. On 19th of April 2010 the university was visited and 33 specimens of $P$. parana were located, collected between 1948 and 1986. Most of the specimens $(n=17)$ originated from Guarapuava, Paraná (1200 m). As a consequence of urban development this habitat was completely destroyed and in recent visits by $\mathrm{O}$. Mielke and one of his students in 2016, no butterfly was recorded. The second largest group of specimens $(n=8)$ was collected by Mielke, between 1971-1981 in the geological state park Vila Velha, near Ponta Grossa. The last P. parana record originated from this site was a single male specimen collected by Andrew Warren in 2004.

On 20-21st April 2010 a two-day visit to the reserve located in the "Campos Gerais do Paraná" was carried out by DB, and AM accompanied by O. Mielke. Many localities were searched within this beautiful reserve, but neither Cuscuta nor $P$. parana were observed. Actually, out of the five polyommatines that fly in Paraná - Hemiargus hanno (Stoll, 1790), Leptotes cassius (Cramer, 1775), Zizula zyna (W. H. Edwards, 1881), Elkalyce cogina (Schaus, 1902) and P. parana - only a few specimens of the first two common and migrant species were observed. In the collection of the Federal University of Paraná there are three $P$. parana specimens collected on 28th of February 1973 by O. Mielke at Vacaria $(950 \mathrm{~m})$ municipality. This city is located in the northern part of Rio Grande do Sul State, not far from the border with Santa Catarina State, a region with altitudinal grasslands. During various field trips in the region carried out earlier by AM and recently in 2015 by HPR, NOM and colleagues, no $P$. parana was found, apparently because almost all natural grasslands were converted into soybean monocultures.

News that $P$. parana was likely observed in mid-December 2008 on Morro Santana, in Porto Alegre (by Cristiano Iserhard, Federal University of Paraná, 
UFP, pers. comm.; the first local record of $P$. parana population was observed by Daniel de Castro, a graduate student at PPG Biologia Animal - Federal University of Rio Grande do Sul) suggested that a population of this rare lycaenid could still exists there. This was the trigger to organise and launch expeditions to rediscover it, learn more about its biology and find the way to protect it and avoid its extinction. During the 7th International Conference on the Biology of Butterflies held between 11-14th of August 2014 in Turku, Finland, the authors DB, HPR and NOM agreed that $P$. parana is an extremely interesting and important species of the Campos Sulinos butterfly fauna, but because of data deficiency it is impossible to properly conserve it and its habitats, as other $P$. parana sightings in Rio Grande do Sul are several decades old. Therefore, the authors decided to launch a series of rescue-search expeditions for this species.

Because sites of recordings of the species were all rock fields, mostly at altitudinal grasslands or hill tops, fields at the top of granitic hills (morros) at the Porto Alegre region fulfilled the requisites for being habitat for the species. The tops of these hills are mostly covered by grasslands, because, due to their rocky nature, the soil is very shallow, sometimes no more than $20 \mathrm{~cm}$ deep and cannot support tree growth. This area is in the contact zone of the Atlantic forest to the north and the Pampa to the south. Botanically the type of habitat is campos sulinos (= southern grasslands) interspersed with semi-deciduous Atlantic forest.

This paper reports the results obtained and presents the information about the expeditions, the localities visited and the observations regarding the life history of $P$. parana, with conclusions on ecology and conservation.

\section{MATERIAL AND METHODS}

Specimens - The identification of Pseudolucia parana by the diagnostic traits ( $c f$. BÁLINT \& BENYAMINI 2001) is straightforward. Therefore $P$. parana material in collections is generally properly identified. This was the case in the visited collections: Federal University of Paraná (Curitiba, Paraná, Brazil) (UFP), Federal University of Rio Grande do Sul (Porto Alegre, Rio Grande do Sul, Brazil) (UFRGS), McGuire Center for Lepidoptera \& Biodiversity (Gainesville, Florida, USA), Natural History Museum (London, UK) and National Museum of Natural History, Smithsonian Institution (Washington DC, USA). Data of the UFP specimens examined are given in Table 1.

With the field expertise of the authors it was also easy to locate and identify $P$. parana individuals in the visited locations. The supposed larval host plant (Cuscuta sp.) is also easy to identify because of its peculiar phenotype and parasitic life history. Plants were identified by consulting SETUBAL et al. (2011).

Vouchers of plants and insects (butterflies, ants) were collected by hand and prepared applying traditional methods. Samples were deposited in UFRGS.

Sites and observations - On the basis of information provided by museum specimens and anecdotal evidences we concentrated our effort in the state 
Rio Grande do Sul, supplemented by a cross-country transect in Uruguay. During our visits to the localities, specimens, early stages, plants, and habitats were recorded with digital cameras, and observations were inscribed as field notes.

Molecular analyses - Molecular analyses were carried out in the Butterfly Diversity and Evolution Lab of the Institute de Biologia Evolutiva (CSICUniversitat Pompeu Fabra), Barcelona, Spain. Legs were taken from recently collected individuals and the mitochondrial marker cytochrome c oxidase subunit I (COI) was amplified and sequenced following the method described in detail by TALAVERA et al. (2013) and by VoDĂ et al. (2015). All new sequences of $P$. parana have been deposited in GenBank (accession numbers MN688540-MN688542). DNA barcoding sequences available in GenBank and BOLD for taxa within the $P$. chilensis species group were also used. A neighbour-joining phylogenetic tree was obtained using a HKY distance model in GENEIOUS PRO 6.0.5 with 100 bootstrap pseudoreplicates to assess the robustness of the tree clades.

Table 1. Pseudolucia parana records in the butterfly collection at the Federal University of Paraná,

Curitiba (state Paraná, Brazil)

\begin{tabular}{|c|c|c|}
\hline \multirow[t]{2}{*}{ Locality, altitude, date, collector } & \multicolumn{2}{|c|}{ wingspan $(\mathrm{mm})$} \\
\hline & male & female \\
\hline Guarapuava, 1200m, Paraná, 28.I.1972, leg. Mielke \& Schneider & 16.5 & \\
\hline Guarapuava, 1200m, Paraná, 28.I.1972, leg. Mielke \& Schneider & 17 & \\
\hline Guarapuava, 1200m, Paraná, 28.I.1972, leg. Mielke \& Schneider & 17 & \\
\hline Guarapuava, 1200m, Paraná, 28.I.1972, leg. Mielke \& Schneider & 17 & \\
\hline Guarapuava, 1200m, Paraná, 28.I.1972, leg. Mielke \& Schneider & 17.5 & \\
\hline Guarapuava, 1200m, Paraná, 28.I.1972, leg. Mielke \& Schneider & 18 & \\
\hline Guarapuava, 1200m, Paraná, 28.I.1972, leg. Mielke \& Schneider & 18 & \\
\hline Guarapuava, 1200m, Paraná, 28.I.1972, leg. Mielke \& Schneider & 18 & \\
\hline Guarapuava, 1200m, Paraná, 28.I.1972, leg. Mielke \& Schneider & 18.5 & \\
\hline Guarapuava, 1200m, Paraná, 28.I.1972, leg. Mielke \& Schneider & 18.5 & \\
\hline Guarapuava, 1200m, Paraná, 28.I.1972, leg. Mielke \& Schneider & 18.5 & \\
\hline Guarapuava, 1200m, Paraná, 28.I.1972, leg. Mielke \& Schneider & 19 & \\
\hline Guarapuava, 1200m, Paraná, 28.I.1972, leg. Mielke \& Schneider & 19.5 & \\
\hline Guarapuava, 1200m, Paraná, 28.I.1972, leg. Mielke \& Schneider & & 17 \\
\hline Guarapuava, 1200m, Paraná, 28.I.1972, leg. Mielke \& Schneider & & 19 \\
\hline Guarapuava, 1200m, Paraná, 28.I.1972, leg. Mielke \& Schneider & & 19.5 \\
\hline Guarapuava, 1200m, Paraná, 28.I.1972, leg. Mielke \& Schneider & & 19.5 \\
\hline Guarapuava, 1200m, Paraná, 28.I.1972, leg. Mielke \& Schneider & & 20 \\
\hline Guarapuava, 1200m, Paraná, 28.I.1972, leg. Schneider & 18 & \\
\hline
\end{tabular}




\begin{tabular}{lcc}
\hline \multicolumn{1}{c}{ Locality, altitude, date, collector } & \multicolumn{2}{c}{ wingspan (mm) } \\
& male & female \\
\hline Guarapuava, 1200m, Paraná, 28.I.1972, leg. Schneider & 18 & 17 \\
Guarapuava, 1200m, Paraná, II.1972, leg. Schneider & & 22 \\
Guarapuava, 1200m, Paraná, II.1972, leg. Schneider & 19.5 \\
Ponta Grossa Campo, 900m, Paraná, IV.1951, leg. Felippe Justas & 19 \\
Ponta Grossa Campo, 900m, Paraná, III.1948, leg. Felippe Justas & 17 \\
Jaguariaiva Park, 1000m, Paraná, 6.II.1986, leg. Mielke \& Casagrande & 16.5 \\
Vila Velha N.P., 900m, Paraná, 4.IV.1981, leg. Mielke & 20 \\
Vila Velha N.P., 900m, Paraná, 7.III.1973, leg. Mielke & 18 \\
Vila Velha N.P., 900m, Paraná, 7.III.1973, leg. Mielke & 17 & \\
Vila Velha N.P., 900m, Paraná, 8.III.1971, leg. Mielke & 17 & \\
Vila Velha N.P., 900m, Paraná, 4.IV.1981, leg. Mielke & & 17 \\
Vila Velha N.P., 900m, Paraná, 6.II.1968, leg. Mielke & & 17.5 \\
Vila Velha N.P., 900m, Paraná, 16.III.1972, leg. Mielke & & 16 \\
Vila Velha N.P., 900m, Paraná, 7.III.1973, leg. Mielke & & \\
Vacaria, 950m, Rio Grande do Sul, 28.II.1973, leg. Mielke & 17 \\
Vacaria, 950m, Rio Grande do Sul, 28.II.1973, leg. Mielke & 18 & \\
Vacaria, 950m, Rio Grande do Sul, 28.II.1973, leg. Mielke & 18 & \\
Average & & \\
\hline
\end{tabular}

\section{FIELDWORK}

\section{Expedition 1}

Location: Morro São Pedro (GPS reading for the location is: $30.18164^{\circ} \mathrm{S}$, 051.11183 ${ }^{\circ} \mathrm{W}$; elevation: $110-130 \mathrm{~m}$ ). Date: 14. XII.2014. Participants: DB, NOM, HPR \& AM.

The site is a private property, situated $17.7 \mathrm{~km} \mathrm{SE}$ of Porto Alegre centre. It is closed to visitors, permanently guarded, and in good ecological condition. On the day of the visit it was opened exclusively to the first "rescue" expedition.

At an elevation of 110-130 m, the forest opens to a grassland ("pampa"). Here the soil cover over the rocks is too thin for supporting trees (Fig. 1). Cuscuta was present by scattered singleton individual specimens. The first $P$. parana, a male, was observed at 12:30 (by HPR) nectaring on a violet flower of Chrysolaena flexuosa (Asteraceae). A female was observed flying from one Cuscuta to another, suggesting that these plants were the hosts, but we did not succeed to observe oviposition. In this habitat we recorded during ca. 40 minutes five adults, usually 
flying about $50 \mathrm{~cm}$ above the ground, maneuvering low in the grass and landing on blades. We proceeded upwards crossing a small forest and at 13:30 arrived to the top. Here at $205 \mathrm{~m}$ a.s.l. (GPS reading: $30.17536^{\circ} \mathrm{S}, 051.11343^{\circ} \mathrm{W}$ ) we found an excellent habitat where most of the suspected host plant and individual butterflies were observed. It was a shallow depression about $70 \mathrm{~m}$ in diameter, near the top of the hill, encircled by forest from one side and protected from the prevailing NW wind, typical in Porto Alegre during the summer. Cuscuta were quite common climbing on grasses, Eryngium sp., Rhynchosia corylifolia (Fabaceae) and other plants (Fig. 11). We stayed in this habitat until 16:00 and observed in total up to 20 butterflies. Males landed on grasses, Eryngium and the Cuscuta host plant - opening their wings in 90 degrees and oscillating their hindwings one opposite the other. A female was observed with closed wings walking low in the vegetation, possibly looking for Cuscuta. The adults were in worn to perfect condition reflecting an active breeding population, possibly with several overlapping broods or a long flight period.

Some Cuscuta branches with flowers were taken to be closely checked for early stages in the laboratories. Five mm long, small black ants that were wandering on the Cuscuta, likely to be hosts for the suspected myrmecophilous $P$. parana larvae, were taken for identification at UFRGS.

\section{Expedition 2}

Location: Morro Santana (GPS reading for the centre of the habitat is 30.06046 $6^{\circ}, 051.12238^{\circ} \mathrm{W}$; elevation: $284 \mathrm{~m}$ ). Date: $15 . X I I .2015$. Participants: DB, NOM, HPR \& AM.

The site is adjacent to the UFRGS campus, within the urban boundaries of the city of Porto Alegre, $7.9 \mathrm{~km}$ from city centre and amidst growing unorganized human settlements. It is intended to be a preservation area and belongs to the university; however, so far, no practical action towards this end has been taken.

At 11:30 the hilltop was reached at $284 \mathrm{~m}$ a.s.l. and, soon after, the first (territorial) male was observed on the narrow track (DB). Until 15:30 several open areas up to the top of the hill were searched, but $P$. parana and Cuscuta were confined to the SW slope from 284 to $295 \mathrm{~m}$ a.s.l. A permanent western cool wind delimited the butterfly activity and most of the ca. 15 observed specimens were flying low near the host plants.

Summarising the visit to Morro Santana: the habitat of $P$. parana is much smaller than in Morro São Pedro and the number of observed $P$. parana was lower too. Here Cuscuta stocks are fewer and scattered. Though legally it is an "area de proteção permanente" (permanent protection area), this location shows obvious signs of human disturbance (fire, trampling, destruction of natural vegetation, erosion, etc.) and is susceptible to illegal occupation. It is definitely in urgent need of protection measures to ensure its conservation. 


\section{Expedition 3}

Location: Park Municipal Saint Hilaire, $14 \mathrm{~km} \mathrm{E} \mathrm{of} \mathrm{Porto} \mathrm{Alegre} \mathrm{(GPS}$ reading of the place: $30.10193^{\circ} \mathrm{S}, 051.08771^{\circ} \mathrm{W}$; elevation: $104 \mathrm{~m}$ ). Date: 18.XII.2016. Participants: DB \& NOM.

The site visited was an open and humid place surrounded by trees with high stocks of Eryngium sp. (Apiaceae), which had buds about to bloom. It was around 10:00 in the morning, warm and damp weather with temperate of $30^{\circ} \mathrm{C}$. The first $P$. parana was detected (by DB) flying very low inside the vegetation. Small and delicate Cuscuta stems were detected climbing especially on long blades of Poaceae. At 11:15 a female was observed flying amongst the grasses, no more than $50 \mathrm{~cm}$ over the soil, that immediately found a Cuscuta plant. After landing she displayed typical polyommatine lycaenid female behaviour: walking on the Cuscuta, oscillating the hindwings, touching the plant with abdomen tip, and laid several eggs. The wings were kept closed during all the time and aligned with direction of sun rays, and staying perpendicular only for short periods. Between 11:15 and 11:37 this individual was followed in the habitat, photographed, and it was observed that the wings were never opened for more than 10 degrees.

Only two $P$. parana individuals were observed in the site (one male, one female). Altogether, in the whole habitat only a few Cuscuta were found, all of them within a circle of $\sim 30 \mathrm{~m}$. It seems that the habitat was unfavorable for Cuscuta, which explains the rarity of $P$. parana at the site. There were clearings in the forest, normally on the top of the hills. The area was dominated by grasses, Eryngium sp. and a local palm (Butia sp.; for their importance see SosINSKI et al.2019). Subsequently, Camilla Goldas, a student on pollination at the Ecology Department (UFRGS), also collected a specimen in the same location.

\section{A visit to $50 \mathrm{~km} \mathrm{~S}$ of Porto Alegre}

Location: Itapuã State Park (GPS reading of the place: $30.36833^{\circ} \mathrm{S}$, 050.99777 $\mathrm{W}$; elevation: 0-263 m). Date: III.2016. Participants: HPR \& colleagues.

Students on a field course, supervised by HPR, incidentally collected a male specimen in "Trilha da Visao" (= trail of vision) in Itapuã State Park. The voucher is in the UFRGS collection and one leg was taken for molecular analysis. The Itapuã State Park is located in the south of the Itapuã District of the municipality of Viamão, Rio Grande do Sul, $57 \mathrm{~km}$ south of Porto Alegre. It is on a promontory bounded to the south and east by Patos Lagoon and to the west by Lake Guaíba. It preserves one of the last remnants of the original vegetation in the Porto Alegre metropolitan area. 


\section{A visit to Uruguay}

Date: 11-17.XII.2018. Participants: DB \& Ofir Tomer.

In the second and third weeks of December 2018 the first author (DB), accompanied by his assistant Ofir Tomer, visited Uruguay in a north-south transect along circa $300 \mathrm{~km}$. Although YUNCKER (1923) found four Cuscuta species in Uruguay, the chances to discover the species in the country were low because one of the authors (NOM) already looked for the butterfly and its larval host plant along the southern border of Brazil, but failed to find them. DB and Ofir Tomer started in north Uruguay, not far from the southern border of Brazil. Based in Melo, they searched to the north, east and west of the city looking for C. taimensis aff. C. racemosa, the host plant of $P$. chilensis in Chile (FERREIRA et al. 2014) (Fig. 23). Then they travelled southward visiting known localities for C. taimensis at: Arroyo Fraile Muerto (Cerro Largo), Arroyo Avestruz Chico (Treinta y Tres) and Minas, Cerro Campanero (Lavalleja). Finally, they searched the southern coast of Uruguay from Montevideo to Cabo Polonio National Park looking for Cuscuta platiloba (González \& Picasso 2015). During a one-week search, they did not find any Cuscuta or P. parana. It is quite possible that their visit was too early in the season, and a later mid-January visit to Uruguay should finally bring the answer whether $P$. parana is present in Uruguay or not.

\section{RESULTS}

\section{The biology of Pseudolucia parana}

Host plant - DB presented the first host plant family tree for the genus Pseudolucia, where P. chilensis was the only feeder on the Cuscuta branch (BENYAMINI 1995: 32). But in a later publication two more species were added to this branch, including $P$. parana with a question mark (BENYAMINI 2013: 171). The expeditions to the granitic hills of Porto Alegre proved that the hypothesis was correct: $P$. parana is tightly associated to the parasitic genus Cuscuta.

The genus Cuscuta contains 145 accepted species worldwide (MABBERLEY 1997, ANONYMOUS2013).Approximately23species are distributedin 16statesalong most of eastern Brazil (LoRENZI 1982, SiMÃo-BIANCHINI \& FERREIRA 2013), but only two are known in Porto Alegre: C. corniculata and C. xanthochortos.

The larval host plant of $P$. parana in Porto Alegre was identified by Priscila Ferreira (Fundação Zoobotânica, Rio Grande do Sul) as C. xanthochortos (Fig. 11), but the other species is a potential host plant as well. Cuscuta species may be toxic (ADLER 2000, GHULE et al. 2011), and implication of the toxicity on the female choice for oviposition is discussed in brief later in this paper. The presence of C. xanthochortos is also noted in the plant database Flora Digital do Rio Grande do Sul \& Santa Catarina (Anonymous 2019). According to this database, the flowering periods of this plant are December and February. 
We believe that the activity of $P$. parana must be synchronised with the flowering periods of the plant, i.e. when the plant has buds, flowers and fruits to feed the larvae.

Egg - Several Cuscuta flowering heads, close to which females were flying, were collected from the visited morros for further inspection. In the laboratory eleven eggs were found; seven (63.7\%) were laid on the host plant's filiform stems, three $(27.3 \%)$ were laid on leaves and one $(9.1 \%)$ on a flower bud. The egg is typical for a lycaenid (MUNGUIRA et al. 2015): flat, bagel-like, 0.5-0.6 $\mathrm{mm}$ in diameter; its colour is white ( $c f$. Fig. 2). Several empty eggs were found, which suggests that the hatching first instar does not consume the eggshell.

Larva - On 15th of December 2014 in Morro Santana, close to the top of the $P$. parana SW slope habitat, at $295 \mathrm{~m}$ a.s.l., eggs and larvae were found on a host plant. First and second instar larvae were yellowish green. L3/L4 larvae were observed consuming Cuscuta flower buds, and were $7 \mathrm{~mm}$ long, yellowish, light green with narrow middorsal brown line with yellow margins and faint subdorsal oblique darker green strips. There were no hairs, dorsal nectary organ was observed, and the head was glossy. The fully grown L5 larva was up to 10 $\mathrm{mm}$ long, smooth, hairless, with cryptic colouration: light green with yellow lines similar to the yellow filiform stems and the white-yellow flowers of Cuscuta. In lateral view, the bolded top segment folds look like saw teeth (Fig. 3). A narrow broken brown dorsal line with yellow borders widened cephalad, subdorsal oblique faint green and yellow dashes and a yellow line around the periphery of the larva (Fig. 4). The head is glossy black.

Pupa - Two brown, smooth pupae were observed at the bottom of the breeding cage under Cuscuta stems. Both were horizontal, 6-7.2 $\mathrm{mm}$ long $(7.5 \mathrm{~mm}$ in P. chilensis), no thoracic girdle was observed (exists in P. chilensis) (Fig. 5). One of them hatched after 5-7 days and a second brood specimen emerged (Fig. 7).

Diapause - The species probably overwinters as mature larva, similarly to the rest of taxa in the genus Pseudolucia and particularly to P. chilensis (BENYAMINI 1995: 15 \& photoplate XIII: 19).

Myrmecophily - The dorsal nectary organ was visible in the caterpillars as a small crossline on the dorsum of the 7 th abdominal segment. Small black ants were wandering over most of the Cuscuta stems and even near resting adults (Fig. 9); they were identified provisionally as Dorymyrmex sp.

Larvae of other species on Cuscuta in the habitats of $\mathrm{P}$. parana - At least four more Lepidoptera larvae were recorded feeding on the local Brazilian Cuscuta spp.

1. A still unidentified hairstreak (Theclinae, Eumaeini) (Fig. 6); possibly the rare Gargina gnosia (Hewitson, 1868), since an adult was collected nearby a sitting female on Cuscuta plant in Morro Santana. In comparison with the larvae of $P$. parana, this larva is slightly larger in the last instar, hairy (with yellow hairs all over its body), the subdorsal signs are triangles and the head is glossy light brownish orange. 
2. Still unidentified hairstreak (Theclinae, Eumaeini); the larva developed on branched spines.

3. Still unidentified hairstreak (Theclinae, Eumaeini); larva with purple spots and green head.

4. A long and narrow moth larva with long hairs.

Ethology - Three territorial males were observed along $20 \mathrm{~m}$ of narrow trail at the top of Morro Santana's $P$. parana habitat. Typical air interceptions of two males included fast circling of one after the other for about five seconds at ca. 20 $\mathrm{cm}$ over the ground, and then they returned to their perch on the edge of low plants along the trail. After landing they opened the wings at 90 degrees and oscillated the hindwings (Fig. 10), which is a typical false head behaviour aiming to attract potential predators to the opposite side of the adult's head (SouraKov 2013, GALICI A et al.2019). Some $30 \mathrm{~m}$ downwind of those territorial males, a motionless female was observed and photographed over a Cuscuta for several minutes, even allowing an ant to get close to it (Figs 8-9).

Adult nectar sources - In addition to the Cuscuta flowers, only few of the available flowering species were recorded as nectar sources for $P$. parana:

1. the most visited flowers were the yellow Aspilia montevidensis (Asteraceae);

2. the scattered purple Chrysolaena flexuosa (Asteraceae), which were in flower;

3. Eryngium paniculatum (Apiaceae); this dominant plant had just begun to bloom; it could become dominant nectar source later in the flight season.

Predators and parasites - We found "U" and "V" marks on the wings of $20 \%$ of the collected specimens. This relatively high percentage suggests that $P$. parana is strongly preyed upon. The marks on the wing membranes were produced most probably by lizards or birds and were divided evenly in the rear margins of the hindwings and the outer margins of the forewings.

During our visit to Morro Santana we photographed a flower crab spider (Thomisidae sp., Araneae) feeding on a P.parana male on an Aspilia montevidensis flower. One of the collected larvae was infected by a tachinid fly (Tachinidae sp., Diptera). 

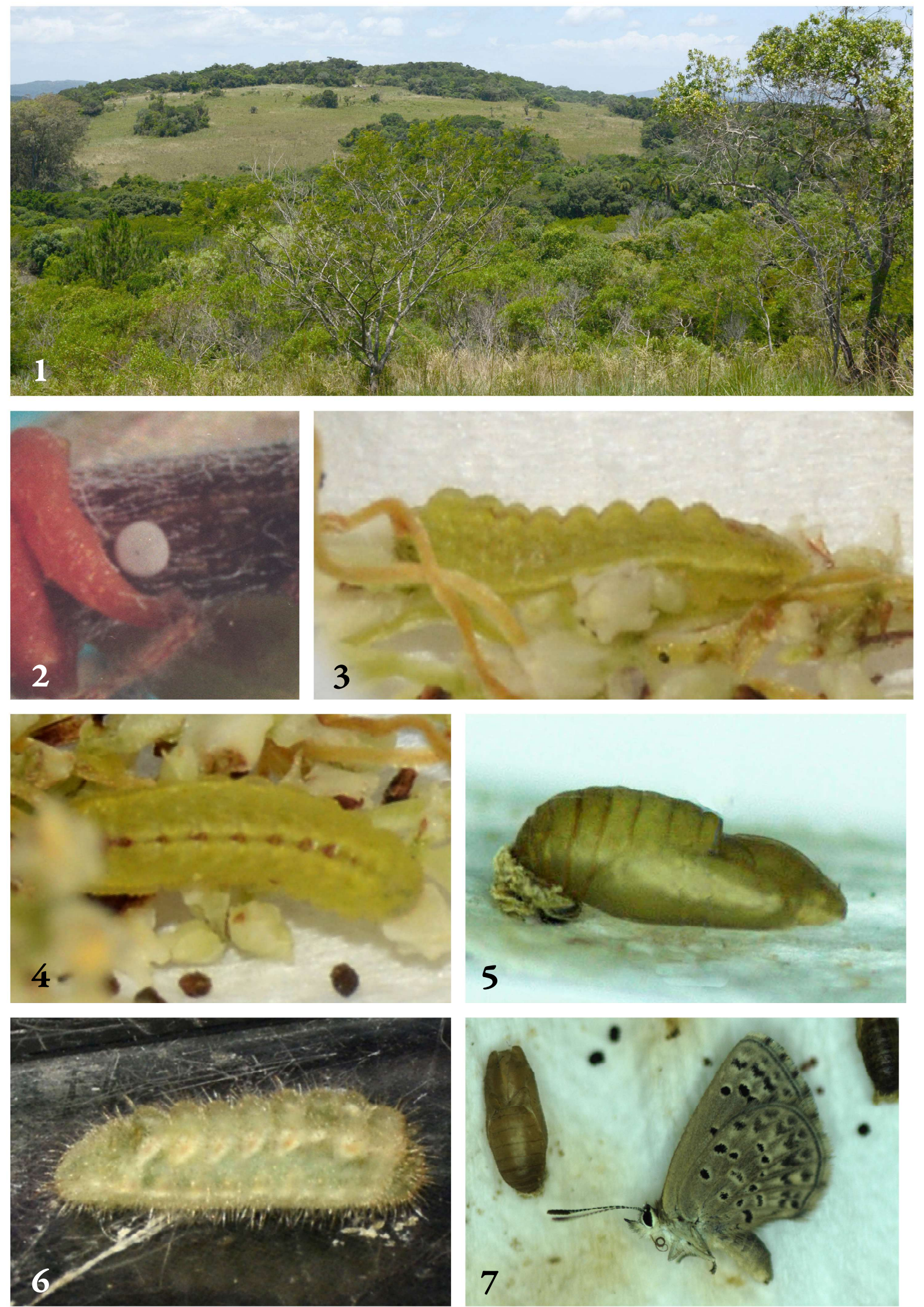
Figs 1-7. Documentations for the biology of Pseudolucia parana Bálint, 1993: 1 = habitat of P.parana at Morro São Pedro, Rio Grande do Sul, Brazil, on 14.XII.2014, showing semi-deciduous Atlantic forest surrounding grasslands ("campos sulinos") $\left(30.18164^{\circ} \mathrm{S}, 051.11183^{\circ} \mathrm{W}\right)$; adults of $P$. parana were observed in the pampa; 2 = egg of P. chilensis (Blanchard, 1852), taken on 12.X.1995, at sea level in Constitucion, Maule, Chile, placed very near to Cuscuta filiform stem; the egg of $P$. parana is identical; $3=$ lateral view of L5 caterpillar showing bolded top saw teeth segments, taken on 15.XII.2014, at 295 m a.s.l., in Morro Santana, Rio Grande do Sul, Brazil; $4=$ dorsal view of L5 caterpillar showing a narrow broken brown line with yellow borders that becomes wider cephalad running along the dorsum, taken on 15.XII.2014, at 295 m a.s.l., in Morro Santana; 5 = lateral view of pupa reared in laboratory, taken on 13.I.2015; $6=$ dorsal view of an eumaeine lycaenid caterpillar taken on 15.XII.2014, in Morro Santana; 7 = pupal case (left) and adult (right) hatched in laboratory, taken on 3.I.2015 (photos 1-4 and 6 by Dubi Benyamini;

5 and 7 by Alfred Moser)

\section{Phylogeny based on molecular analysis}

In the phylogenetic tree based on mitochondrial COI sequences (Fig. 22), the taxon parana is recovered as part of the $P$. chilensis species group and, in particular, as sister to the clade formed by $P$. chilensis $+P$. sosneada Benyamini et Bálint, 2015, with 100\% bootstrap support and divergence (minimum uncorrected genetic distance) of $1.7 \%$, which approximately translates to $0.7-1.1$ million years, according to the generally accepted substitution rates for COI.

The recently discovered $P$. "torotorensis" (GUERRA SERRUDO et al. 2018) and the rediscovered $P$. jujuyensis Bálint, Johsnon et Eisele, 2000 are sister taxa, with a $100 \%$ bootstrap support and diverged by $1.1 \%$ in COI. The minimum genetic distance between P."torotorensis" + P. jujuyensis, to P. parana is $2.9 \%$.

The last known population of Paraná (Villa Velha) is about $900 \mathrm{~km}$ north from the populations of Rio Grande do Sul (cf. Figs 12-21). Their minimum genetic distance is $0.3 \%$, which suggests that they have been isolated since the last glaciation or even more (at least 12,000 years ago); however, note that only one specimen from Paraná was analysed. 

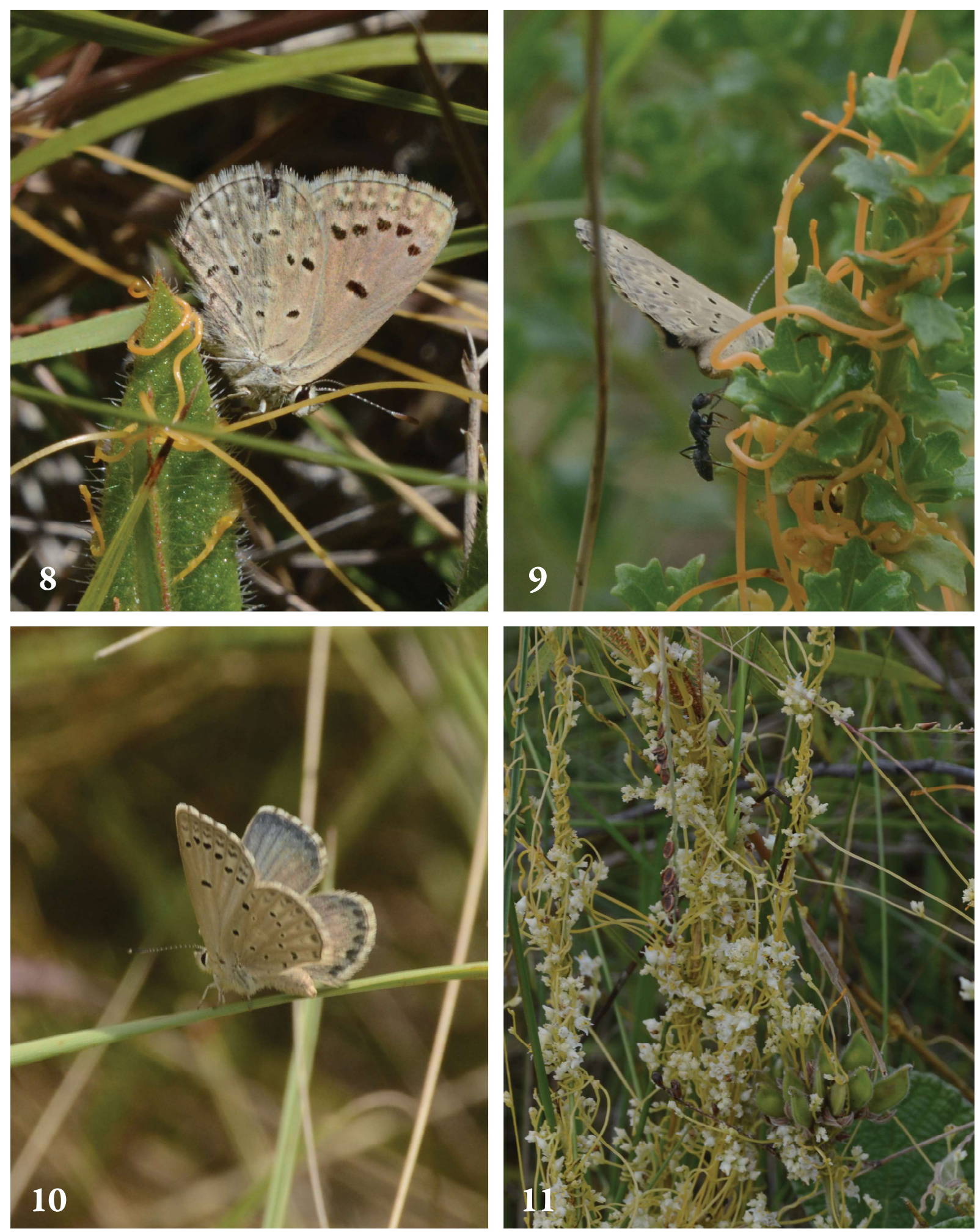

Figs 8-11. Host plant documentation of Pseudolucia parana Bálint, 1993: 8 = a female searching suitable place to lay an egg, the wiggling Cuscuta is well visible close to her abdomen, taken on 18.XII.2016, in Parque Municipal Saint Hilaire, 104 m, Rio Grande do Sul, Brazil; $9=$ an ant worker (Dorymyrmex sp.?) near the ovipositing female, taken on 15.XII.2014, at $295 \mathrm{~m}$ a.s.1., in Morro Santana, Rio Grande do Sul, Brazil; 10 = perching male, taken on 15.XII.2014, in Morro Santana; 11 = larval host Cuscuta globiflora, taken on 14.XII.2014, in Morro San Pedro, 205 m, Rio Grande do Sul, Brazil (photos by Dubi Benyamini) 

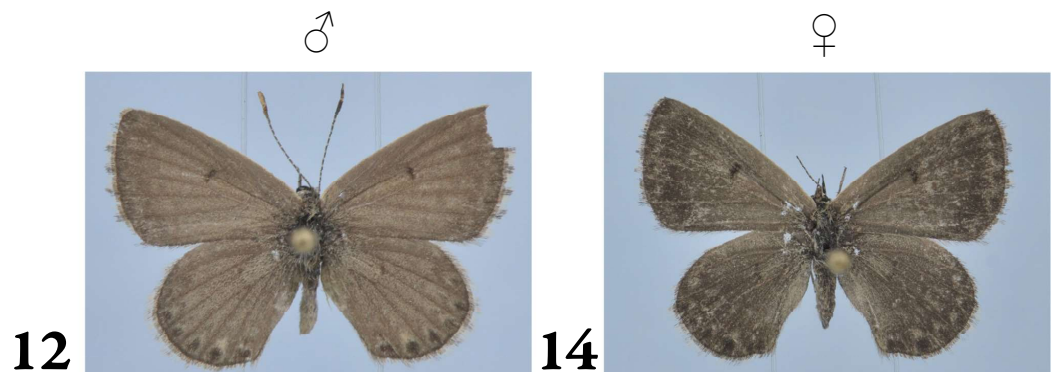

13
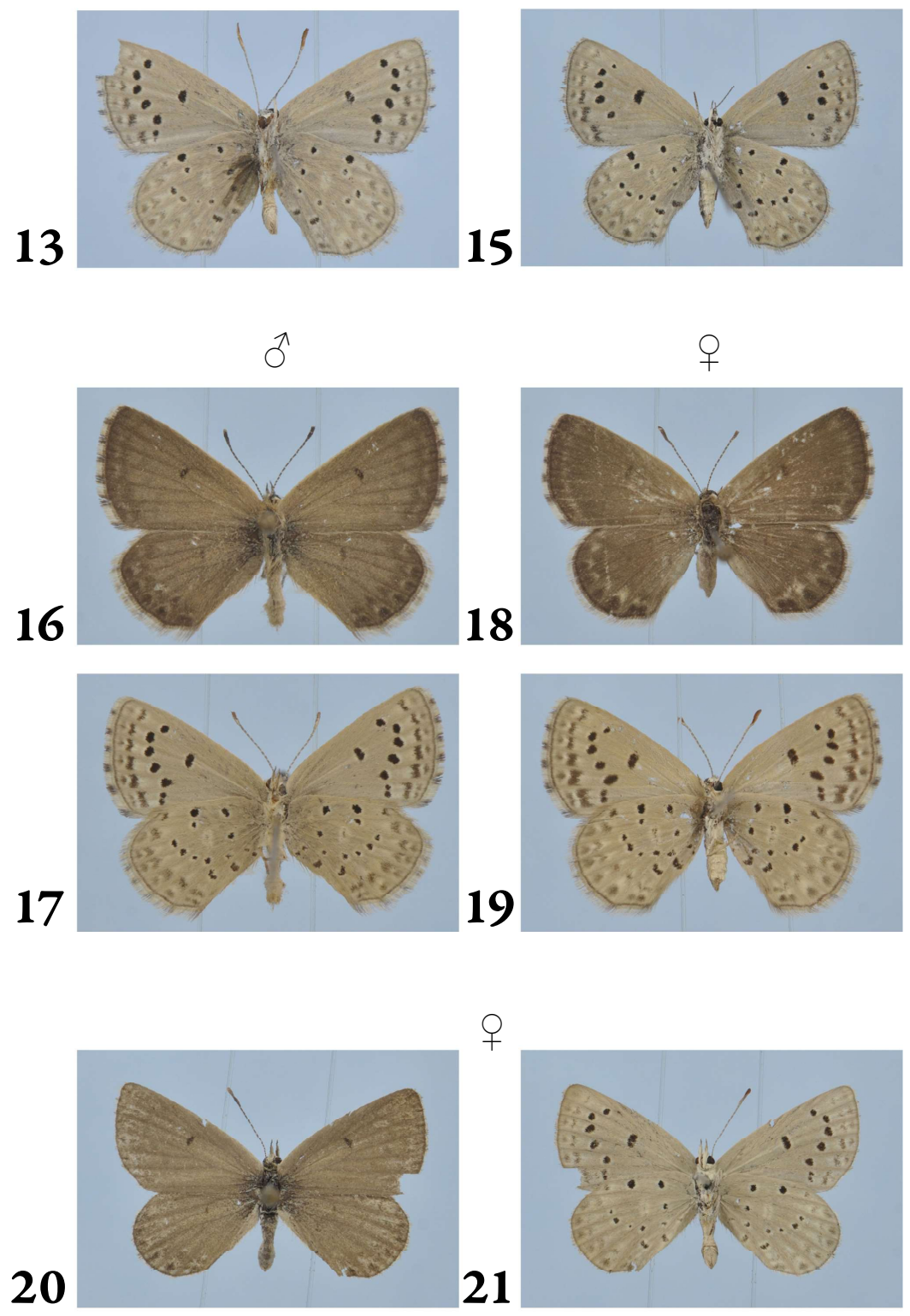

Figs 12-21. Museum specimens of Pseudolucia parana Bálint, 1993 from Brazil, under same magnification. The Rio Grande do Sul specimens have more delicate wing surface pattern compared to that of Paraná specimens: $12-13=$ male and $14-15=$ female (recto and verso) from Morro Santana, Rio Grande do Sul, 285 m, 15.XII.2014, leg. D. Benyamini; 16-17 = male and 18-19 = female (recto and verso) from Guarapuava, Paraná, $1000 \mathrm{~m}, 28.1 .1972$, leg. O. Mielke \& Schneider (male) and from Ponta Grossa, Vila Velha, Paraná, 900 m, 7.III.1973, leg. O. Mielke (female); 20-21 = female (recto and verso) from Vacaria, Rio Grande do Sul, 950 m, 28.II.1973, leg. O. Mielke. Scale: forewing costa length of the Fig. $12=11 \mathrm{~mm}$ (photos by Dubi Benyamini) 


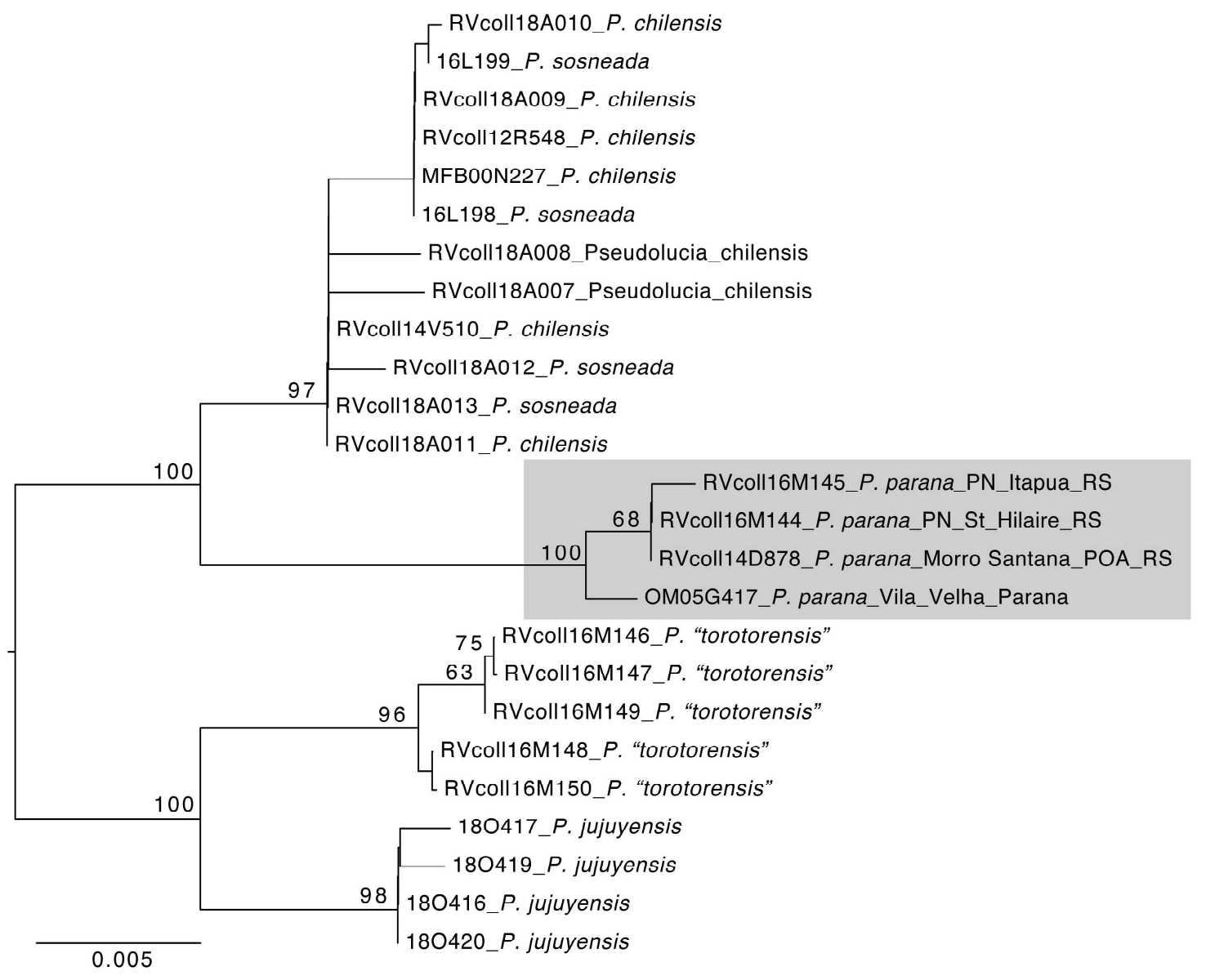

Fig. 22. Neighbour-joining tree based on the COI sequences for Pseudolucia parana Bálint, 1993 (highlighted), and its closest relatives. Bootstrap support values $>50$ are indicated. Scale represents 0.005 substitutions per site

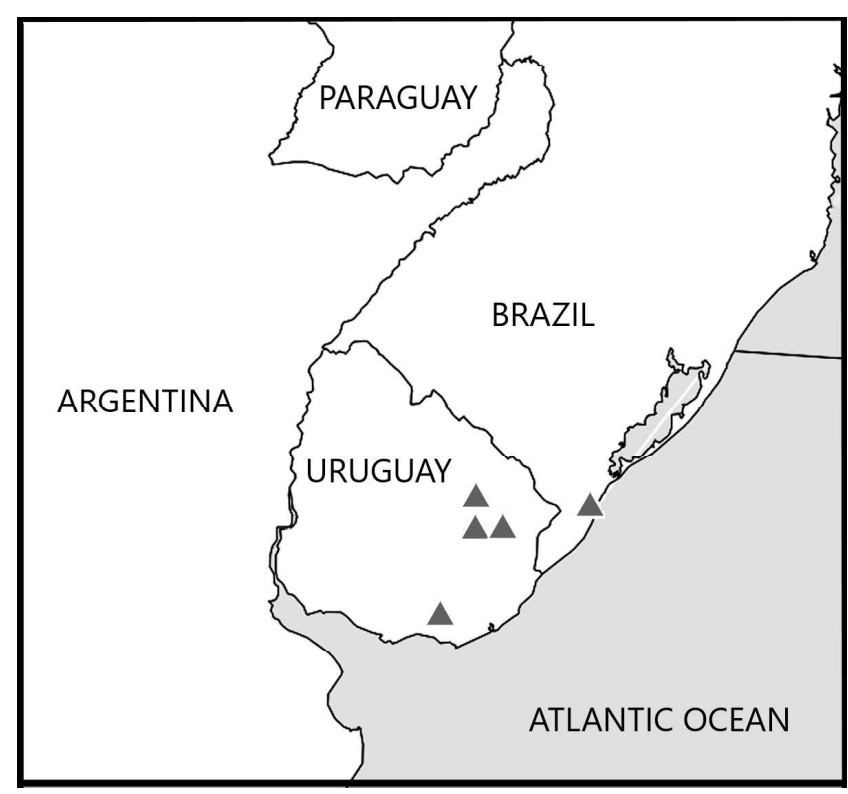

Fig. 23. Distribution of Cuscuta taimensis in southern Brazil and eastern Uruguay (redrawn on the basis of FERREIRA et al. 2014) 


\section{DISCUSSION}

The toxicity of Cuscuta and possible implications of the larval diet

Species of Cuscuta seem to be particularly prone to accumulate alkaloids from a variety of host plants and, for example, the toxic glucoside trehalose has been detected in C. reflexa (CzYGAN et al. 1988, WAGSTAFF 2008, Burrows \& Tyre 2012). Benya mini (1995: 45-48 \& Fig. G) placed $P$. chilensis female with its reddish brown warning colouration in the centre of a large Chilean mimicry ring. While the larvae consume toxic Cuscuta, other reddish-brown mimics consumed other toxic plants, i.e. all members of the $P$. andina species group consume host plants of the genus Astragalus, known as addictive to livestock and called in Spanish "Yerba Loca" (the crazy plant). So, why did P. parana not develop warning colours that could serve as protection against predators? The same question applies to the two other species of the $P$. chilensis species group: (1) P. jujuyensis Bálint, Johnson et Eisele, 2000 (no orange markings) (BÁLINT et al. 2000) and (2) P. sosneada (which has minimal orange markings on the female's upper forewings) (BENYAMINI \& BÁLINT 2015).

A potential hypothesis is that some species of Cuscuta are less toxic than others, or that toxicity depends on which plant the Cuscuta is parasitizing. However, differences in the communities of predators might also be an explanation.

Classification and taxonomy of Pseudolucia parana based on traditional and molecular characters

$P$. parana belongs to the $P$. chilensis species group of Pseudolucia, which is characterized by the following adult morphological traits: (1) dorsal wing surfaces of both sexes are coloured with brown pigments, without sexual dimorphism typical of the genus; (2) the pattern of the ventral wing surface is typical polyommatine (with spots), grossly contrasting most of the other members of the genus (with arrow-head marks) (cf. NA BOKOv 1945); (3) aedeagus extremely stout and the suprazonal portion is very short and pointed; (4) the long and membranous female ductus is heavily folded. All these characters were considered to be plesiomorphic, suggesting a basal position of the species group in the phylogeny of the genus (NABOKOV 1945, BÁLINT \& BENYAMINI 2001).

Previous molecular analyses (VIla et al. 2011, Guerra SERrudo et al. 2018) confirmed this hypothesis: the $P$. chilensis species group was monophyletic and sister to the rest of the genus. In the phylogenetic tree based on mitochondrial COI sequences here presented (Fig. 22), the taxon P. parana is recovered as part of the $P$. chilensis species group and, in particular, as sister to the clade formed by 
P. chilensis $+P$. sosneada. Based on the tree divergences, we can estimate an age for $P$. parana of approximately $1 \mathrm{M}$ year old.

Further division apparently happened during the last glaciation or even before, when Porto Alegre and Paraná populations were split. The two stocks seem to be genetically and morphologically slightly distinct (Figs 12-19), but a single specimen from Paraná was sequenced and further evidence has to be collected to support their taxonomic distinction.

The proposed phylogeny of $P$. parana underlines the importance of the granitic hills of Porto Alegre region: they provide the last refuges for relict taxa that evolved under conditions very different from the current situation (SETUBAL et al. 2011).

\section{Distribution, human influence, sampling}

Butterfly distribution analyses often suffer serious data deficiency and available records frequently show the activity of lepidopterists rather than the actual distribution of the species. In the case of $P$. parana, however, the following considerations underline that the data available on the species reflect that the species is indeed rare, very specialised and habitat specific. The intensive lepidopterological investigation in Brazil started in the 19th century, and the Southern Region (states Paraná, Santa Catharina and Rio Grande do Sul) were some of the most intensively sampled ones. Because of the large number of European immigrants and climate similarities to their original home, "Nova Teutônia" in southern Brazil offered better conditions and logistics compared with other areas of those times, resulting an intensive butterfly trade and earlier lepidopterofauna surveys than in other parts of South America. However, classical workers, like Fritz Müller (1821-1897), Adolpho Pompilio P. Mabilde (1850-1892), Hans Fruhstorfer (1866-1922), Czesław Marian Bieżanko (1895-1986) and Fritz Plaumann (1902-1994) were all keen to explore and describe the biodiversity of the region, including the smallest butterflies, such as $P$. parana, but they did not collect the species. More recently, i.e. at least in the last three or four decades, quite a few entomologists worked intensively on the butterflies of southern Brazil (see, e.g, Corseuil et al. 2004, Dolibaina et al. 2011, Mielke 1995, Morais et al. 2007, PAZ et al. 2013, Siewert et al. 2014, Teston \& Corseuil 2008, and references therein), including three of us (NOM, HPR and AM).

Therefore, we suggest that the species is indeed very rare. In the early period of lepidopterology, samples were available only for Schaus, who described the taxon. This rarity can be confirmed by the observation that historical samples of $P$. parana can be found only in the Natural History Museum (London, UK), which contains a portion of Dukinfield E. Jones' collection via the Rothschild Bequest (BÁLINT 1993). Jones collected the Lycaena griqua type material preserved in the Smithsonian Institution, and also in the McGuire Center (Gainesville, Florida, USA). 
The data for Paraná State where "Lycaena griqua" was discovered obviously testify that the morro habitats are under considerable threat, as at the turn of the 20th-21st centuries the land use in Paraná state has become more intensive to a manner that destroys the ecosystem. In spite of intensive search in the second decade of the 20th century, the species could not be found in the localities of Castro, Guarapuava, Jaguariaiva, Ponta Grossa Campo and Vila Velha. Dolibaina et al. (2011) report that natural fields were present until the mid1970 s in the Guarapuava region, where the last records for $P$. parana originate (see Table 1); then the remnants were increasingly replaced by monocultures. In 2011, only three small patches under five hectares were left, two of which have now disappeared. The lepidopterofauna of this phytophysiognomy is critically under threat, as no protected area provides such vegetation in that state; $P$. parana is most probably extinct there.

In Rio Grande do Sul the current situation is not much better: grassland physiognomies are hardly ever included in preserved areas, and almost always these areas are surrounded by huge expanses of environmental matrix unfavorable for butterfly dispersal. It is symptomatic that all four locations where $P$. parana was found are within parks. However, in addition to the actual fields where they were found are very small, the level of implementation and protection is satisfactory in only one of these (Itapuã State Park).

In 2014, P. parana was included in the red list of endangered species of the state of Rio Grande do Sul in the category Endangered (EN; B1ab (iii)) (Decree No. 51.797, of 8 September 2014), given the very few published records for the species, although researchers have been working in their region in the last decade. Its global extent was restricted $\left(\sim 4000 \mathrm{~km}^{2}\right)$, its natural habitats - the native rock and altitude fields - being under increasing anthropogenic pressure and threatened with fragmentation and destruction by various types of activity: agriculture, livestock, fire, forestry, urbanization and even climate change.

Recently, the status of $P$. parana was reassessed in a workshop for definition of priority areas in the Pampa for conservation and it was strongly recommended that its status should be changed to critically endangered (CR B2b(iii)): currently, in addition to the very few records described above, this endemic grassland species is restricted to the granitic hills of Porto Alegre, and by ecological niche modeling and satellite habitat assessment, its whole area of occupancy is estimated to be smaller than $3.5 \mathrm{~km}^{2}$ ). Although this species is listed as not evaluated globally by the IUCN, given that it is a Brazilian endemic that has not been documented outside the states of Paraná and Rio Grande do Sul, the data here provided indicate a global status of Critically Endangered for P. parana.

$P$. parana is an important species because it indicates the unique ecosystem confined to the top of these granitic hills at this southernmost region (Fig. 24). Consequently, it could be considered as a flagship species for the conservation of these habitats. Only recently has the butterfly fauna of Campos Sulinos been in the focus of studies. Data has grown a lot in the last ten years, but much information 
is still lacking. Given the speed at which native fields are being altered, protective actions are essential, as there is a real risk that other species will become extinct without even being documented. There is already strong evidence of extinct species in the natural fields in regions of south Brazil, given the nearly complete destruction or degradation of these habitats. Some species, however, such as $P$. parana, can still be found as small remnants, in need of urgent conservation effort. Many other species in similar situations might exist. The best strategy for their conservation is more thorough research on their biology and ecology, and to make the conservation and restoration of their natural habitats a priority.

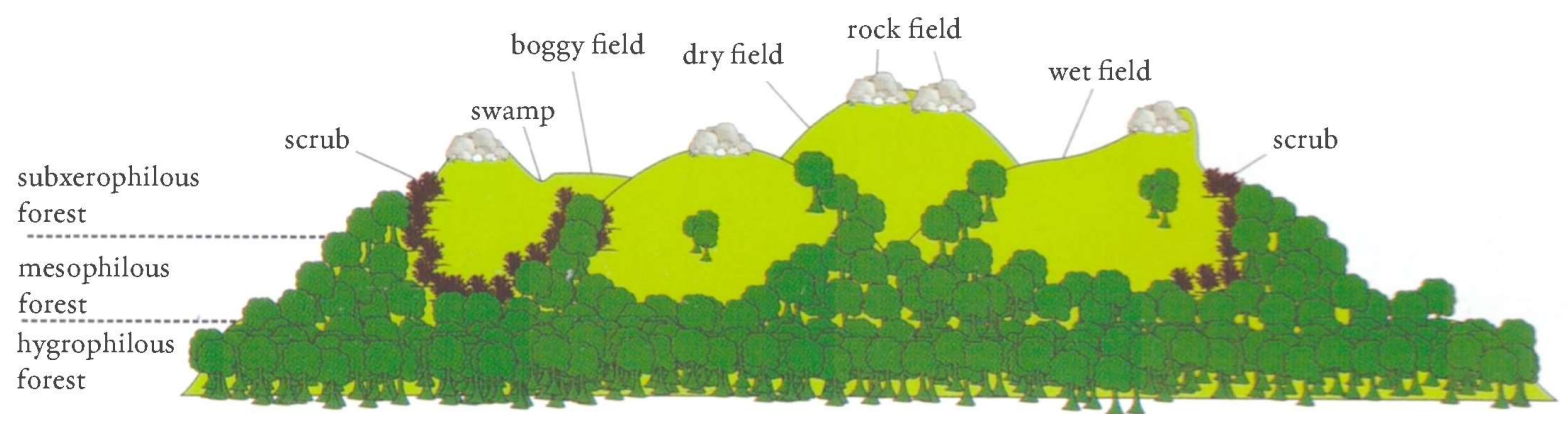

Fig. 24. Altitudinal gradient schematic profile and position of rural and forest communities along the top of a hill ("morro") in Porto Alegre, Brazil. The habitats of Pseudolucia parana are on the top region where rock fields are situated (based on SETUBAL et al. 2011)

Acknowledgements - Olaf Mielke, Lucas Kaminski and Cristiano Iserhard provided information on early $P$. parana observations. The larval host plant of $P$. parana in Porto Alegre, Cuscuta xanthochortos, was identified by Priscila Ferreira (Fundação Zoobotânica, Rio Grande do Sul). Camilla Goldas of the Ecology Department (UFRGS) collected $P$. parana in Itapuã State Park. Ofir Tomer participated in the expedition to Uruguay. Lea Benyamini prepared the colour plates. Gergely Katona contributed in various technical issues. Hearty thanks are due to all of them. Genetic analyses were supported by project CGL2016-76322-P (AEI/FEDER, UE); Cecília Corbella helped in the laboratory. Chico Mendes Institute for Biodiversity Conservation (ICMBio) provided the collecting license, and the Brazilian National System of Biodiversity Research/ National Network for Research and Conservation of Lepidoptera (SiSBiota/RedeLep) helped with financial support. Nicolás Oliveira Mega was funded by Coordination of Improvement of Higher Level Personnel National Postdoctoral Program (PNPD/CAPES - grant \#23038.8306/2010-62), Helene Piccoli Romanowski by CNPq (grant \#304273/2014-7) and Roger Vila by the Spanish Ministerio de Ciencia, Innovación y Universidades (grant PRX19/00067). In Hungary, Zsolt Bálint was supported by the grants OTKA 11741 and 115724 . 


\section{REFERENCES}

AdLER L. S. 2000: The ecological significance of toxic nectar. - Oikos 91: 409-420.

https://doi.org/10.1034/j.1600-0706.2000.910301.x

Andrade B. O., Bonilha C. L., Overbeck G. E., Vélez-Martin E., Rolim R. G., Bordingon S. A. L., Schneider A. A., Vogel Ely C., Lucas D. B., Garcia É. N., dos Santos E.D., Toschelsen F. P., Vieira S. M., Silva Filho P. J. S., Ferreira P. M. A., Trevisan R., Hollas R., Campestrini S., Pillar V. D. \& Boldrini I. I. 2019: Classification of South Brazilian grasslands: Implications for conservation.- Applied Vegetation Science 19: 168-184. https://doi.org/10.1111/avsc.12413

Anonymous 2013: The Plant List. Version 1.1. - http://www.theplantlist.org/ [Accessed 31 October 2019.]

BÁlint Zs. 1993: A Catalogue of Polyommatine Lycaenidae (Lepidoptera) of the Xeromontane Oreal Biome in the Neotropics As Represented in European Collections. - Reports of the Museum of Natural History, University of Wisconsin (Stevens Point) 29: 1-42.

Bálint Zs. \& Benyamini D. 2001: Taxonomic notes, faunistics and species descriptions of the austral South American polyommatine lycaenid genus Pseudolucia (Lepidoptera: Lycaenidae): the chilensis and collina species-groups. - Annales historico-naturales Musei nationalis hungarici 93 : 107-149.

BÁLINT Zs., Johnson K. \& EISELE R. 2000: Description of the sister species of Pseudolucia chilensis (Blanchard, 1852) (Lepidoptera: Lycaenidae). - Folia entomologica hungarica 61: 169-179.

Benyamini D. 1995: Synopsis of Biological Studies of the Chilean Polyommatini (Lepidoptera, Lycaenidae). - Reports of the Museum of Natural History, University of Wisconsin (Stevens Point) 52: ii-i + 1-51.

Benyamini D. 2013: Pseudolucia balinti sp.n. of the plumbea-sibylla species group in CentralWest Argentina (Lepidoptera, Lycaenidae: Polyommatinae). - Folia entomologica hungarica 74: 157-174.

Benyamini D. \& BÁlint Zs. 2015: Descriptions of eight new Pseudolucia species from Argentina with an updated list of species distributed in the austral regions of South America (Lepidoptera, Lycaenidae: Polyomatinae). - Folia entomologica hungarica 76: 173-216. https://doi.org/10.17112/FoliaEntHung.2015.76.173

Brow N K. S. JR. 1993a: Selected Neotropical species. - In: NeW T. R. (ed.): Conservation Biology of Lycaenidae (Butterflies). Occasional Paper of the IUCN Species Survival Commission no. 8. IUCN, Gland, pp. 146-149.

Brow N K. S. JR. 1993b: Neotropical Lycaenidae: an overview. - In: New T. R. (ed.): Conservation Biology ofLycaenidae (Butterflies). Occasional Paper of the IUCN Species Survival Commission No.8. IUCN, Gland, pp. 45-61.

Burrows G. E. \& Tyre R. J. 2012: Toxic Plants of North America. - Wiley Blackwell, 1390 pp. https://doi.org/10.1002/9781118413425

Corseuil E., Quadros F. C., Teston J. A. \& Moser A. 2004: Borboletas (Lepidoptera: Papilionoidea e Hesperioidea) coletadas no Centro de Pesquisa e Conservação da Natureza Pró-Mata. 4: Lycaenidae. - Divulgaçôes do Museu de Ciências da PUCRS 9(1): 65-70. 
Czygan F.-C., Wessinger B. \& Warmuth K. 1988: Cuscuta and its property to take up and accumulate alkaloids of hostplants. - Biochemie und Physiologie der Pflanzen 183: 495-501. https://doi.org/10.1016/S0015-3796(88)80008-8

Dolibaina D. R., Mielke O. H. H. \& Casagrande M. M. 2011: Borboletas (Papilionoidea e Hesperioidea) de Guarapuava e arredores, Paraná, Brasil: um inventário com base em 63 anos de registros. - Biota Neotropica 11(1): 341-354. https://doi.org/10.1590/S1676-06032011000100031

Ferreira P. P. A., Dettke G. A., Waechter J. L. \& Miotto S. T. S. 2014: Cuscuta taimensis (Convolvulaceae, Cuscuteae), a new species from South America. - Brittonia 66(3): 269-273. https://doi.org/10.1007/s12228-014-9329-1

Galicia E. N., Luis Martínez M. A. \& Cordero C. 2019: False head complexity and evidence of predator attacks in male and female hairstreak butterflies (Lepidoptera: Theclinae: Eumaeini) from Mexico. - PeerJ 7: e7143 1-14. https://doi.org/10.7717/peerj.7143

Ghule R. S., Venkatnarayanan R., Thakare S. P., Jain H., Ghule P. R. 2011: Analgesic activity of Cuscuta campestris Yuncker a parasitic plant grown on Nerium indicum Mill. Journal of Advanced Pharmacy Education \& Research 1: 45-51.

González A. \& PiCasso G. 2015: Guía de flora del Parque Nacional Cabo Polonio. - Ministerio de Vivienda, Ordenamiento Territorial y Medio Ambiente, Montevideo, 223 pp.

Guerra Serrudo J. J., Siebel G., Vila R., Benyamini D. \& Bálint Zs. 2018: A remarkable record of the genus Pseudolucia from Bolivia (Lepidoptera: Lycaenide). - Opuscula Zoologica Instituti Zoosystematici et Oecologici Universitatis Budapestinensis 49(1): 23-31. https://doi.org/10.18348/opzool.2018.1.23

LORENZI H.1982: Plantas Daninhas do Brasil: terrestres, aquáticas, parasitas, tóxicas emedicinais. Instituto Plantarum, Nova Odessa, $425 \mathrm{pp}$.

MABBerley D. J. 1997: The Plant-Book. A portable dictionary of the vascular plants. - University Press, Cambridge, xvi+858 pp.

Mielke C. G. C. 1995: Papilionoidea e Hesperioidea (Lepidoptera) de Curitiba e seus arredores, Paraná, Brasil, com notas taxonômicas sobre Hesperiidae. - Revista Brasileira de Zoologia 11(4): 759-776. https://doi.org/10.1590/S0101-81751994000400018

Morais A. B. B., Romanowski H. P., Iserhard C. A., Marchiori M. O. \& Segui R. 2007: Mariposas del Sur de Sudamérica (Lepidoptera: Hesperioidea y Papilionoidea). - Revista Ibero-Americana de Ciências Ambientais 35: 29-46.

Munguira M. L., Martín J., García-Barros E., Shahbazian G. \& Cancela J. P. 2015: Morphology and morphometry of Lycaenid eggs (Lepidoptera: Lycaenidae). - Zootaxa 3937(2): 201-247. https://doi.org/10.11646/zootaxa.3937.2.1

NАвокоv V. 1945: Notes on Neotropical Plebejinae (Lycaenidae, Lepidoptera). - Psyche 52: 1-61. https://doi.org/10.1155/1945/65236

Paz A. L. G., Roma Nowski H. P. \& de Mor AIs A. B. 2013: Distribution of Satyrini (Lepidoptera, Nymphalidae)in RioGrandedoSulState,southernBrazil.-EcologicalResearch 28(3):417-426. https://doi.org/10.1007/s11284-013-1035-z 
Robisns R. K. 2004: Introduction to the Checklist of Eumaeini (Lycaenidae). Tribe Eumaeini. Appendix: Lycaenidae: Eumaeini. - In: LAM As G. (ed.): Checklist of Neotropical Lepidoptera, Part 4. Association for Tropical Lepidoptera and Scientific Publishers, Gainesville, pp. xxiv-xxx, 118-137, 275-282.

SCHaus W. 1902: Descriptions of new American butterflies. - Proceedings of the United States National Museum 24(1262): 383-460. https://doi.org/10.5479/si.00963801.1262.383

Setubal R. B., Boldrini L. L. \& Abreu-Ferreira P. M. 2011: Campos Dos Morros de Porto Alegre. - Associação Sócio-Ambientalista, Igré, $254 \mathrm{pp}$.

Siewert R. R., Iserhard C. A., Romanowski H. P., Callaghan C. J. \& Moser A. 2014: Distribution patterns of riodinid butterflies (Lepidoptera: Riodinidae) from southern Brazil. - Zoological Studies 53(15): 1-10. https://doi.org/10.1186/1810-522X-53-15

Simão-Bianchini R. \& Ferreira P. P. A. 2013: Cuscuta. - Lista de Espécies da Flora do Brasil. Jardim Botânico do Rio de Janeiro. http://floradobrasil.jbrj.gov.br/jabot/floradobrasil/FB6978 [Accessed 31 October 2019.]

Sosinski Jr. Ê. E., Urruth L. M., Barbieri R. L., Marchi M. M. \& Martens S. G. 2019: On the ecological recognition of Butia palm groves as integral ecosystems: Why do we need to widen the legal protection and the in situ/on-farm conservation approaches? - Land Use Policy 81: 124-130. https://doi.org/10.1016/j.landusepol.2018.10.041

Sourakov A. 2013: Two heads are better than one: false head allows Calycopis cecrops (Lycaenidae) to escape predation by a Jumping Spider, Phidippus pulcherrimus (Salticidae). Journal of Natural History 47(15-16): 1047-1054.

https://doi.org/10.1080/00222933.2012.759288

Talavera G., Lukhtanov V. A., Pierce N. E. \& Vila R. 2013: Establishing criteria for higherlevel classification using molecular data: the systematics of Polyommatus blue butterflies (Lepidoptera, Lycaenidae). - Cladistics 29: 166-192.

https://doi.org/10.1111/j.1096-0031.2012.00421.x

Teston J. A. \& Corseuil E. 2008: Nimfalídeos (Lepidoptera, Nymphalidae) ocorrentes no Rio Grande do Sul, Brasil. Parte VI. Nymphalinae e Satyrinae. - Biociências 16(1): 42-51.

Vila R., Bell Ch. D., Macniven R., Goldma-Huertas B., Ree R. H., Marshall Ch. R., Bálint Zs., Johnson K. D., Benyamini D. \& Pierce N. E. 2011: Phylogeny and palaeoecologyof Polyommatus blue butterflies show Beringia was aclimate-regulatedgateway to the New World. - Proceedings of the royal Society of London (B) 278(1719): 2737-2744. https://doi.org/10.1098/rspb.2010.2213

Vodă R., Dapporto L., Dincă V. \& Vila R. 2015: Why do cryptic species tend not to cooccur? A case study on two cryptic pairs of butterflies. - PLoS One 10(2): 1-18 e0117802. https://doi.org/10.1371/journal.pone.0117802

Wagstaff D. J. 2008: International Poisonous Plants Checklist: An Evidence-based reference. CRC Press, 464 pp. https://doi.org/10.1201/9781420062533

Wilson J. B., Peet R. K., Dengler J. \& PÄrtel M. 2012: Plant species richness: the world records. - Journal of Vegetation Science 23: 796-802.

https://doi.org/10.1111/j.1654-1103.2012.01400.x

YunCker T. G. 1923: The genus Cuscuta. - Memoirs of the Torrey Botanical Club 18: 113-331. 